\title{
Women and the Discourse of Marriage: A Critical Analysis of Jane Eyre and Pride and Prejudice
}

\author{
Gabriely Diniz ${ }^{1 *}$ \\ ${ }^{1}$ State University of Paraiba, Brazil \\ *Corresponding author: Gabriely Diniz: gabrielycqdiniz@gmail.com
}

\section{OPEN ACCESS}

Citation: Diniz G. (2020) Women and the Discourse of Marriage: A Critical Analysis of Jane Eyre and Pride and Prejudice. Open Science Journal 5(4)

Received: $6^{\text {th }}$ April 2020

Accepted: $24^{\text {th }}$ June 2020

Published:20 ${ }^{\text {th }}$ October 2020

Copyright: (c) 2020 This is an open access article under the terms of the Creative Commons Attribution License, which permits unrestricted use, distribution, and reproduction in any medium, provided the original author and source are credited.

Funding: The author(s) received no specific funding for this work

Competing Interests: The author has declared that no competing interests exists.

\begin{abstract}
:
This short article aims to compare the discourse of the characters Jane Eyre from the eponymous novel by Charlotte Brontë, and Elizabeth Bennet from Pride and Prejudice by Jane Austen, in which both of them refuse marriage proposals. As criteria of comparison its pointed: i) the reasons why they decided to decline the proposals, ii) the way they express their emotions during the moments, iii) the reactions of the male characters after the women's answers.
\end{abstract}

Keywords: Jane Eyre, Pride and Prejudice

\section{Introduction}

Taking a closer look at Jane Eyre (1847), it tells the story of an orphan who lives with her wealthy aunt and cousins but is mistreated by them. After a confrontation with her family, she is sent to the Lowood School where she makes friends, but suffers from abuse and oppression. After finishing school, Jane goes to work at Mr. Edward Rochester's house as a governess and falls in love with her employer. Charlotte's novel is considered to be one of the first works in Bildungsroman genre.

Pride and Prejudice (1813) around Elizabeth Bennet (Lizzie), the second daughter of five, who has a witty and sarcastic personality and strong opinions about marriage. As her sister, Jane, gets interested in the newcomer Mr. Bingley, Lizzie meets his best friend, Mr. Fitzwilliam Darcy; a shy and rich bachelor who believes to be in a condition of superior birth. Elizabeth and Darcy get involved in a plot where class, wealth and pride are major themes, as the novel follows their development towards abandoning proud and biased positions.

The literary texts are analyzed through Fuller's (1994) manifest for the nineteenth century women, and Alves (1999) about love and submission of women in the Victorian era. The character's reactions will be contextualized into 
its time period and author's writing style. Also, differences on the plot will be considered to base women's choices.

In Jane Eyre, during Jane's wedding ceremony, Mr. Mason interrupts to claim that Mr. Rochester is already married and cannot make official a new ceremony. Edward explains Jane that his wife has gone mad and is hidden in the attic under Grace Poole's supervision, which explains the apparitions and noises in the house. After moments of anguish, Jane has a conversation with her beloved and refuses an outrageous proposal of living as his mistress in Thornfield.

"Jane, do you understand what I want of you? Just this promise- 'I will be yours, Mr. Rochester".

"Mr. Rochester, I will not be yours."

"Jane", recommenced he, with a gentleness that broke me down with grief, and turned me stone cold with ominous terror - for this still voice was the pant of a lion rising. "Jane, do you mean to go one way in the world, and let me go another?"

"I do."

"Jane, (bending toward and embracing me), do you mean it now?"

"I do".

"And now? softly kissing my forehead and cheek."

"I do-" Extricating myself from restraint rapidly and completely.

"Oh, Jane, this is bitter! This- this is wicked. It would not be wicked to love me."

"It would be to obey you." (BRONTË, 2013, p. 369).

As according to Fuller (1994), women should decide not to accept "the glitter of trinkets, spacious houses and plentiful domestic services, which they [men] intend offer you through these means" (p.87); as so, Jane refuses Rochester's proposal due to Rochester's lies and to honor her principles. During the conversation, she feels like "a hand of fiery iron grasped my [her] vitals" (p.481), and she struggles to fight against her feelings and hesitates to give him an answer. Jane declines Edward's proposal and fears his reaction because even when he treats her in a gentle way, his voice seems like "the pant of a lion rising" (p.481). Rochester answers restraining her in an embrace and kissing her face, but Jane manages to escape and emphasises - in answer to his questioning upon the wicked character of their love - that it would be wicked to obey him.

For Alves (1999, p.107), women in the Victorian era were forbidden to demonstrate love or desire. This fact could be a strong basis for Jane Eyre's principles and a reason for her refusal to Mr. Rochester's outrageous proposal. In this time period, such an offer would not come from a woman's mouth, as she the female writers wanted to show no harming intentions to male readers (op. cit). After the refusal, Rochester says that not loving him would be a "bitter" and "wicked" (p. 482) act, however, Jane replies that obeying him would be indeed. This position taken by the character in this passage could show a clear position of the author to present a feminist characterization for Jane Eyre's figure, as the writer herself assumes this part.

As for the autobiographical features present in Charlotte Brontë's text, when we examine her life facts carefully, it is possible to encounter some resemblances with Jane Eyre's life and the presence of writing as a form of escapism to the young writer's struggle. This phenomenon can characterize Charlotte's proximity with the protagonist of the novel and her ideologies. Also, as an expression of the personal influence of her life, in Jane Eyre, the characters who caused any type of 
"suffering" to the Jane during the novel finish the story with sad endings, as Charlotte's declared desire for her real life abusers.

In Pride and Prejudice, after discovering that Mr. Darcy interfered in Bingley's plans to marry Jane Bennet and supposedly prived Mr. Wickham of his rightful wealth, Lizzie is surprised by Darcy's marriage proposal and refuses it with a proud and audacious speech.

"Why a so evident desire of offending and insulting me, you chose to tell me that you liked me against your will, against your reason, and even against your character? Was not this some excuse to incivility, if I was uncivil? But I have other provocations. You know I have. Had not my feelings decided against you - had they been indifferent, or had they even been favourable, do you think that any consideration would tempt me to accept the man who has been the means of ruining, perhaps for ever, the happiness of a most beloved sister?"

As she pronounced these words, Mr. Darcy changed colour; but the emotion was short, and he listened without attempting to interrupt her while she continued' (AUSTEN, 2016, p. 219).

In Elizabeth's speech, she exposes her reasons to decline the proposal based on the case of Jane and Mr. Wickham in a courageous manner, pointing the lack of tactfulness of Darcy. For Fuller (1994), women's hearts demand nobility and honor, and if they have no purity or mercy, they cannot perform their roles as parents, husband, lovers, and so forth. As Darcy evaluates the proposal acceptance as a certain matter, he ignored her "demands" and does not expect that the plot against Jane and Bingley, the misrepresentation upon Wickham, and his non-tactful speech; could stand in Lizzie's heart as an impression of his character.

Observing Darcy's answer to Elizabeth, it is possible to notice his indignation on the situation, as he elicits her offences towards him and indicates the inferior condition of her family, which is a lack of noticing that he could not achieve any success on his proposal by insulting her background.

"And this," cried Darcy, as he walked with quick steps across the room, "is your opinion of me! This estimation in which you hold me! I thank you for explaining so fully. My faults, according to this calculation, are heavy indeed! But perhaps", added he, stopping in his walk, and turning towards her, "these offences might have been overlooked, had not your pride been hurt by my honest confession of the scruples I have long prevented my forming any serious design. [...] Nor am I ashamed of the feelings I related. They were natural and just. Could you expect to rejoice in inferiority of your connections? - to congratulate myself on the hope of relations, whose condition in life is so decidedly beneath my own?"(AUSTEN, 2016, p. 220).

Elizabeth feels mixture of feelings during the conversation, starting on astonishment and progressing to painful sadness as Darcy eventually leaves the house. She feels grateful for his feeling but angry for his pungent pride. At first, as Lizzie answers the proposal, Darcy feels surprised and gets angry with her justifications, also ashamed of exposing his love. When he storms out of the house, Jane falls in physical weakness and cries for half and hour, implicitly proving her feelings towards him. 
Concluding, in the case of both couples, the characters manage to have a happy ending after getting in consonance and progressing to understand each others characteristics. The male characters Mr. Rochester and Mr. Darcy start to recognize Jane and Elizabeth as women who present remarkable strength and deserve better treatment and less selfishness from their parts, which leads to the ladies accepting their proposals at the end of the novels. Charlotte Brontë and Jane Austen provide in the protagonists a load of emotions and approach the progression of the characters and its facets to humanize and make the audience identify with them until nowadays.

\section{References:}

Alves, Ivia. "Amor e Submissão: Formas de Resistência da Literatura Feminina?" Literatura e Feminismo: Propostas Teoricas e Reflexoes Críticas, by Christina Ramalho, Elo, 1999, pp. 107115.

Austen, Jane. Pride and Prejudice. Wisehouse Classics, 2016.

Brontë Charlotte. Jane Eyre. London: Simon \& Schuster, 2015.

Fuller, Margaret, and Donna Dickenson. Woman in the Nineteenth Century and Other Writings. Oxford University Press, 1994. 